\title{
肝組織浸潤リンパ球表面抗原の two-color
}

\section{flow cytometric analysis}

$\begin{array}{lllllll}\text { 竹原 } & \text { 徹郎* } & \text { 林 } & \text { 紀夫* } & \text { 片山 } & \text { 和宏* } & \text { 佐々木 裕* } \\ \text { 笠原 } & \text { 彰紀* } & \text { 房本 } & \text { 英之* } & \text { 佐藤 } & \text { 信紜* } & \text { 加藤 道夫** } \\ \text { 益沢 } & \text { 学** } & \text { 鎌田 } & \text { 武信* } & & & \end{array}$

要 旨：慢性肝炎の肝組織浸潤リンパ球サブセットを明らかにするために，22例の慢性肝炎患 者の針生検材料からリンパ球を分離し flow cytometryによる検討を行った。慢性肝炎患者の 肝組織内では末梢血に比し，HLA-DR 抗原を表出した活性型 T 細胞が有意に増加し，しかも GPT 低值群に比し GPT 高値群でより增加していた。䀒組織内では CD8+細胞が増加していた が,これは cytotoxic $\mathrm{T}$ 細胞扣よび suppressor $\mathrm{T}$ 細胞の增加によるものであった。一方, CD4 ${ }^{+}$ 細胞は減少していたが，これは suppressor inducer T 細胞の減少によるもので, helper $\mathrm{T}$ 細 胞はむしろ有意に増加しており，肝炎の発症に helper $\mathrm{T}$ 細胞が関与していることが示唆され た。また, 訮組織内では $\mathrm{Fc}$ receptor を表出した $\mathrm{T}$ 細胞が増加しており, cytotoxic $\mathrm{T}$ 細胞と 共に肝細胞障害の effector 細胞の一つである可能性が示㥖された. 本方法は従来の免疫組織学 的方法に比し，2 重染色が容易でより定量的である点で有用な方法であった。

索引用語： 肝組織浸潤リンパ球 two-color flow cytometry 慢性肝炎

\section{腥 言}

慢性肝炎の肝細胞障害の成立には，細胞性免疫が関 与している ${ }^{1,22}$ 。旰細胞障害に関与するリンハ球分画に ついては，免疫組織学的検討が諸家によりなされてお $\eta^{3-8)}, \mathrm{CD}^{+}$細胞の増加, $\mathrm{CD} 4^{+}$細胞の減少, $\mathrm{NK}$ 細胞 の減少等が報告されている，近年，モノクロナール抗 体とフローサイトメトリーの応用により $\mathrm{CD} 8^{+}$細胞は cytotoxic $\mathrm{T}$ と suppressor $\mathrm{T}$ 細胞に, $\mathrm{CD} 4$ 細胞は helper $\mathrm{T}$ と suppressor inducer $\mathrm{T}$ 細胞に更に細分さ れの), また, NK 細胞にも複数の系列が存在することが 明かとなっだ10.しかし，従来の免疫組織学的方法では 定量的な 2 重染色の点で限界があったため, 肝組織内 のリンパ球分画のより詳細な検討は困難であった。そ こで，今回我々は慢性肝炎患者の肝生検標本より浸潤 リンパ球を分離し，2次元フローサイトメトリーによ ろ検討を行った。

\section{材料わよひ方法}

1）肝組織漫洞単核球およひ末梢血単核球の分離

- 大阪大学第 1 内科

“国立大阪病院消化器科

〈受付日1990年 2 月20日〉
9 例の B 型慢性肝炎, 13例の非 B 型慢性肝资患者の 腹腔鏡下肝生検時に得られた約 $1 \mathrm{~cm}$ の訮生検標本を 水冷下に phosphate buffered saline (PBS) にて十分 洗浄し，26G の皮下注針にて機械的に細切した，得ら れた細胞浮遊液から Ficoll-Hypaque 比重遠心法にて 単核球分画を分離した ${ }^{11 !}$ 。この方法により1標本当り $3 \times 10^{4}$ ないし $6 \times 10^{4}$ 個の単核球を回収し得た。同时

Table 1 Monoclonal antibodies used to discriminate lymphocyte subsets.

\begin{tabular}{|c|c|c|}
\hline & $\begin{array}{l}\text { FITC. } \\
\text { labeled }\end{array}$ & $\begin{array}{l}\text { PE: } \\
\text { labeled }\end{array}$ \\
\hline Activated $\mathrm{T}$ & Leu4 (CD3) & HLA-DR \\
\hline $\begin{array}{l}\text { Activated } \\
\text { cytotoxic/suppressor } T\end{array}$ & Leu2a(CD8) & HLA-DR \\
\hline $\begin{array}{l}\text { Cytotoxic } T \\
\text { Suppressor } T\end{array}$ & Leu2a(CD8) & Leu15(CD11) \\
\hline $\begin{array}{l}\text { Activated } \\
\text { helper/inducer } T\end{array}$ & Leußa (CD4) & HLA-DR \\
\hline $\begin{array}{l}\text { Helper } T \text {, Suppressor } \\
\text { inducer } T\end{array}$ & Leu8 & Leu3a(CD4) \\
\hline Natural killer & Leu7 & Leullc(CD16) \\
\hline Fc receptor-bearing $T$ & Leu4(CD3) & Leul1c(CD16) \\
\hline
\end{tabular}

FITC, fluorescein isothiocyanate; $\mathrm{PE}$, phycoerythrin. 
Peripheral

HLA-DR

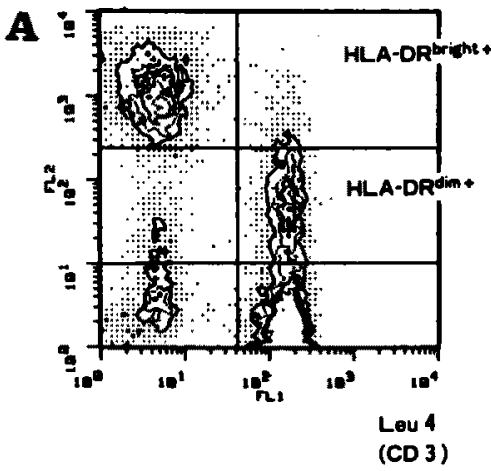

Intrahepatic

HLA-DR

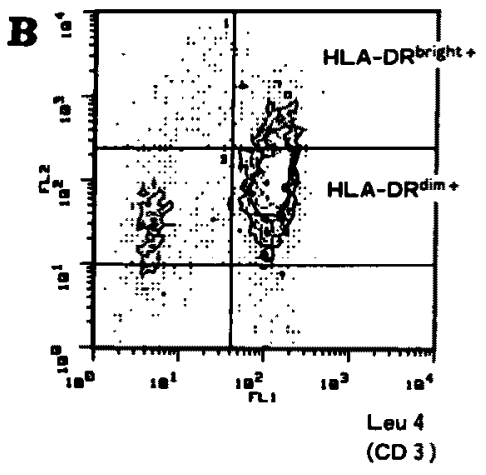

Fig. 1 Two-color flow cytometry of CD3 vs. HLA-DR on peripheral lymphocytes (A) and intrahepatic lymphocytes (B) from a patient with chronic hepatitis $B$.

Peripheral

Leu15

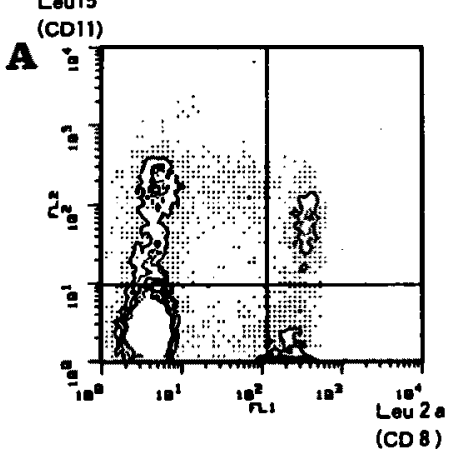

Leu 3 a

$$
(\mathrm{CD} 4)
$$

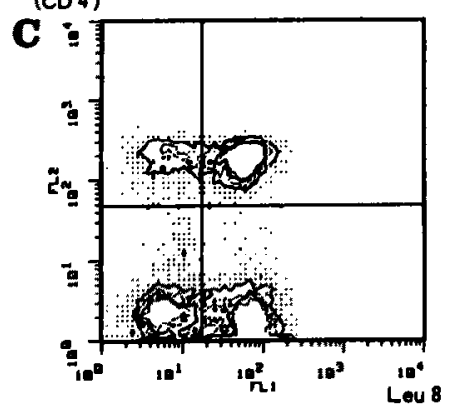

Intrahepatic

$$
\text { Leu15 }
$$
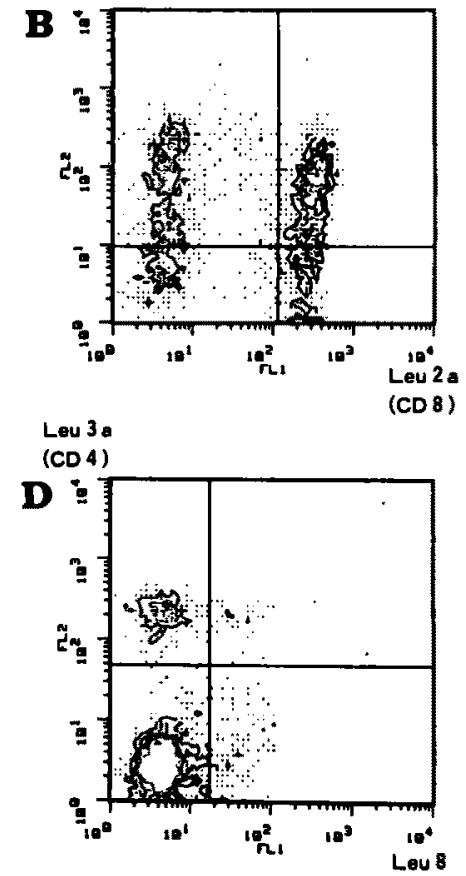

Fig. 2 Two-color flow cytometry of CD8 vs. CD11 (A, B) and Leu8 vs. CD4 (C, D) on peripheral lymphocytes (A, C) and intrahepatic lymphocytes (B, D) from the same patient as in Fig. 1. 
に, 肝生検時の慢性肝炎患者㧍よび8 例の健常者の一 ベリン加末梢血上り比重遠心法にて単核球分画を分離 した。

\section{2) 直接営光抗体法}

使用したモノクローナル抗体は Becton Dickinson (Mountain View, CA) 上り睡入し, 使用前に至適量 を決定した。得られた単核球をTable 1 に示寸組合せ の fluorescein isothiocyanate (FITC) おょび phycoerythrin (PE) 標識モノクローナル抗体で 2 重染 色し， $0.5 \%$ バラフォルムフルデビドで固定した。

3) flow cytometric analysis

Becton Dickinson 社製の FACScan system t使用 した，前方扣よび側方散乱光を用いてリン八球分画に gateをかけ，畋組織浸門リンバ球については 3,000５,000個，末佾血リン八球については10,000個 の綀胞について解析した，原則として，对応するイム ノグロブリンコントロールを陰性対象として陽泩細胞 を決定したが，HLA-DR 抗原についてはB 細胞と同
程度に明るく染まる細胞をHLA-DR抗原陽性

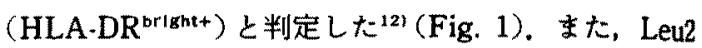
a 抗体は NK 細胞を暗く, suppressor/cytotoxic T 細 胞を明るく染めることが知られているので10)，明るく

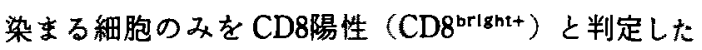
(Fig. 2).CD16抗原については，明るく染まる細胞と 暗く染まる細胞が存在するが棌，両細胞ともCD16陽 性と判定した（Fig. 3).

\section{4) 統計処理}

Student's $\mathrm{t}$ 検定を行った。

$$
\text { 結 果 }
$$

慢性肝炎患者の末梢血 リンバ球分画は健常者に比し 有意の変化を認めなかった(Fig. 4〜7). 慢性肝炎の肝 組織浸潤 リンパ球の67.1\%が CD3陽性の $\mathrm{T}$ 細胞でそ のうち28\%が HLA.DR 抗原陽性の活性型 $\mathrm{T}$ 細胞 ${ }^{13)}$ あった。 B 細胞の浸潤は $4.3 \%$ と减少していた（Fig. 4).旰生検前 1 力月間の血清 GPT 值が200以上の群と 以下の群で比較すると, この活性型 $\mathrm{T}$ 細胞の漫濯仕
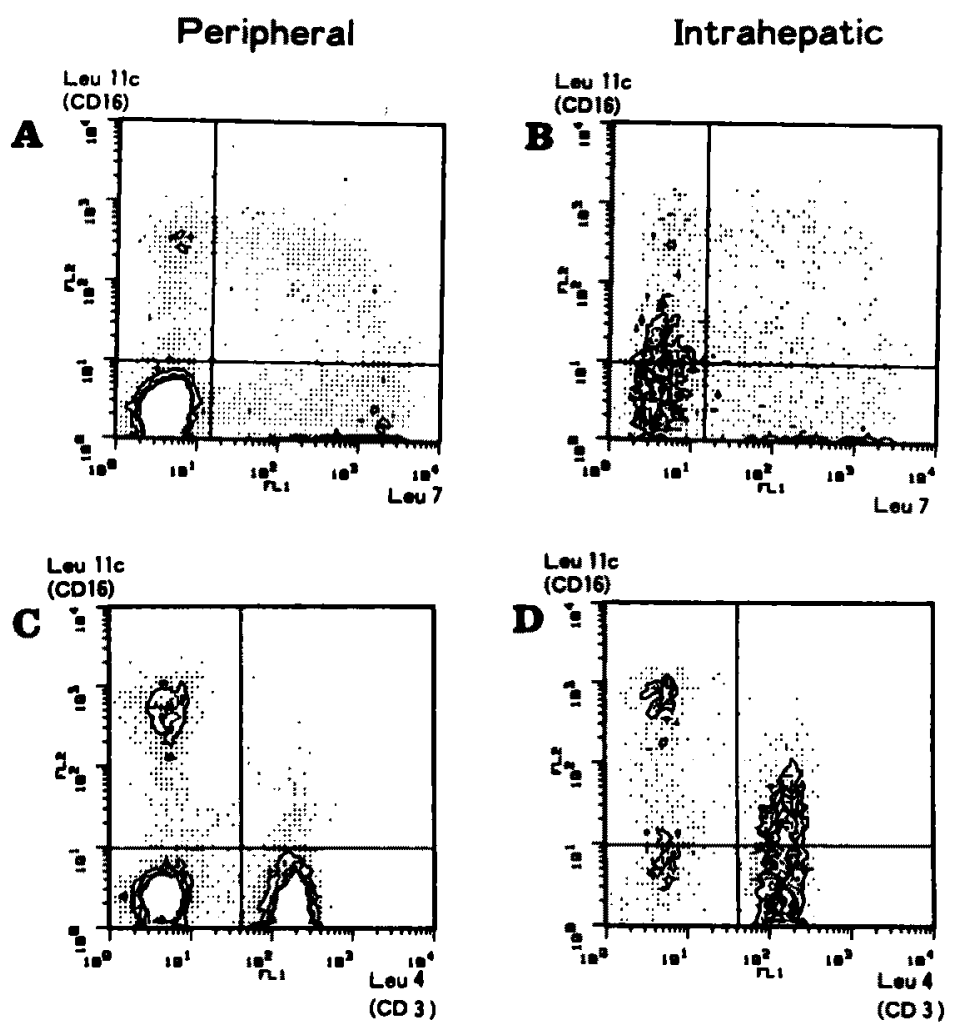

Fig. 3 Two-color flow cytometry of Leu7 vs. CD16 (A, B) and CD3 vs. CD16 (C, D) from the same patient as in Fig. 1. 


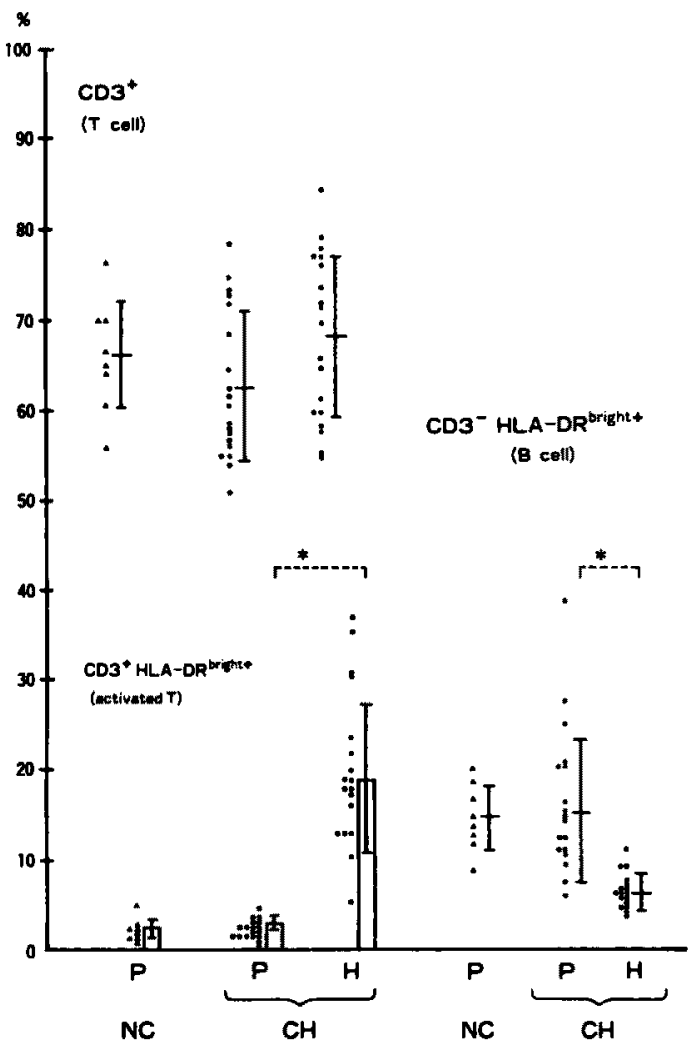

Fig. 4 Percentages of $\mathrm{CD}^{+}, \mathrm{CD}^{+} \mathrm{HLA} \cdot \mathrm{DR}^{\mathrm{br} \text { ight+ }}$, and CD3-HLA-DR ${ }^{\text {bright+ }}$ cells in peripheral lymphocytes and intrahepatic lymphocytes from patients with chronic hepatitis compared with normal controls. Mean values $\pm S . D$. are indicated by horizontal bars. Closed triangles $(\boldsymbol{A})$, normal subjects; open circles (O), chronic hepatitis B patients; closed circles (O), chronic hepatitis non-B patients. $\mathrm{NC}$, normal control ; $\mathrm{CH}$, chronic hepatitis ; $\mathrm{P}$, peripheral lymphocyte ; $\mathrm{H}$, intrahepatic lymphocyte. *, p $<0.01$.

GPT 高值群で有意に増加していた（Table 2). CD8陽性の cytotoxic/suppressor $\mathrm{T}$ 細胞は35.4\% と従来の報告と同様に末梢血に比し增加していたか， これは cytotoxic T 細胞 (19.1\%) と共に suppressor T細胞（16.3\%）の增加によるるのであったまた，

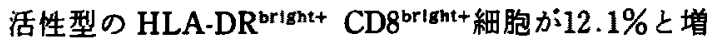
加していた(Fig. 5).CD4陽性の helper/inducer T 細 胞は16.8\%と従来の報告と同様に減少していたが，こ れは suppressor inducer $\mathrm{T}$ 細胞（3.9\%）の著減によ るものであって, helper T 細胞 (12.9\%) はむしろ有
Table 2 Lymphocyte subsets in chronic hepatitis in relation to alanine aminotransferase level.

\begin{tabular}{|c|c|c|}
\hline & $\begin{array}{l}\text { High ALT } \\
\text { group } \\
\text { (10) }\end{array}$ & $\begin{array}{l}\text { Low ALI } \\
\text { group } \\
\text { (12) }\end{array}$ \\
\hline $\mathrm{CD}^{+}$ & $67.6 \pm 8.7$ & $66.8 \pm 9.1$ \\
\hline $\mathrm{CD}^{+}$HLA-DR ${ }^{\text {brisht+ }}$ & $25.1 \pm 7.8^{*}$ & $13.8 \pm 4.2$ \\
\hline CD8 & $39.1 \pm 8.3$ & $32.4 \pm 8.1$ \\
\hline $\begin{array}{l}\text { CD8 } \\
\text { HLA A-DRtent }\end{array}$ & $15.2 \pm 7.2^{* *}$ & $7.5 \pm 3.3$ \\
\hline $\mathrm{CD}_{4}{ }^{+}$ & $16.0 \pm 3.8$ & $17.5 \pm 5.4$ \\
\hline CD4 $4^{4}$ HLA-DR ${ }^{\text {bright+ }}$ & $4.0 \pm 2.3$ & $2.5 \pm 1.0$ \\
\hline $\mathrm{CD}^{+} \mathrm{CD}^{-} 6^{+}$ & $18.4 \pm 6.2$ & $16.3 \pm 8.1$ \\
\hline
\end{tabular}

High ALT group and low ALT group represent groups of patients whose serum ALT levels were more and less than $200 \mathrm{U} / \mathrm{L}$, respectively. All values are given as percentages of all lymphocytes and expressed as mean \pm S.D. ALT, alanine aminotransferase; ", significantly different from the other group, $p<0.01 ; " \cdot$, significantly different from the other group, $p<0.02$. Numbers in parentheses are numbers of patients.

意に末梢血に比し增加していた。 HLA-DR ${ }^{\text {bright }+} \mathrm{CD}^{+}{ }^{+}$細胞が3.3\%と增加していた (Fig. $6)$.

Leu7とCD16の 2 重染色では, 通常 NK 活性が強い と考えられている Leu7- CD16+細胞が $19.0 \%$ と肝組 織では增加していた。してかし通常この細胞は，Fig， 3 の末梢血の例でみられるよ5に,CD16が明るく染まっ てくるが，肝で増加している細胞はCD16が暗く染 まってくる細胞であり，CD3と 2 重染色をすることに よりこの細胞の多くはT細胞であることが明らかと なった（Fig. 7).

\section{考案}

僈性肝炎患者の末梢血リンバ球分画については，材 料が容易に入手できることもあり，諸家により報告が なされているが，一定の結論は得られていない。 Thomas $5^{14)}$ は CD4/CD8は HBe 抗原陽性慢性肝炎 患者ては隇少し， HBe 抗体陽性患者では増加していた と報告しており，恩地ら ${ }^{(5)}$ は慢性活動性肝炎の増悪期 に増加し寛解期に減少していたと報告している.近年, 長谷川 による検討を行い，慢性肝炎患者と健常者の間ではり ンパ球分画に有意差がなかったと報告している，今回 の我々の検討でる，末梢血リンハ球分画は慢性肝炎患 者と健常者閻で有意な差を認めなかった。したがって， 肝内の免疫反応の解析には，末梢血の検討では不十分 


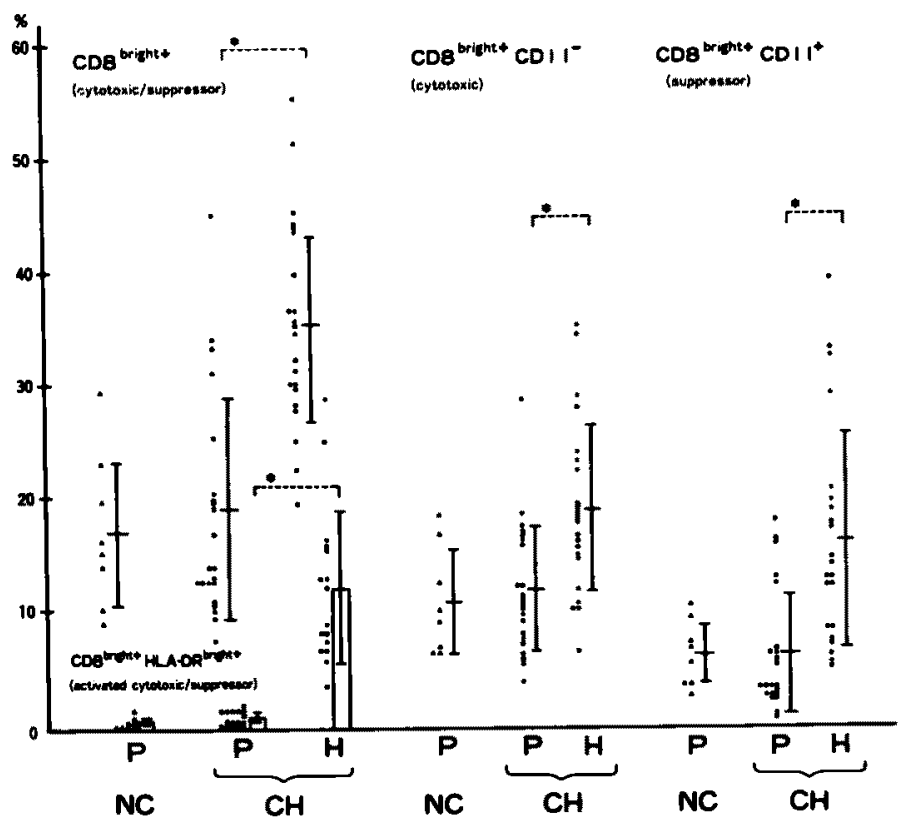

Fig. 5 Percentages of CD8 ${ }^{\text {bright+ }}, \mathrm{CD}^{\text {bright+ }}$ HLA-DR ${ }^{\text {bright+ }}, \mathrm{CD}^{\text {bright+ }} \mathrm{CD11}{ }^{-}$, and CD8 brisht+ $\mathrm{CD}^{\text {1 }}{ }^{+}$cells. Mean values \pm S.D. are indicated by horizontal bars. Closed triangles (A), normal subjects; open circles $(\mathrm{O})$, chronic hepatitis $B$ patients; closed circles (O), chronic hepatitis non-B patients. NC, normal control; $\mathrm{CH}$, chronic hepatitis; $\mathrm{P}$, peripheral lymphocyte; $\mathrm{H}$, intrahepatic lymphocyte. *, $\mathrm{p}<0.01$.

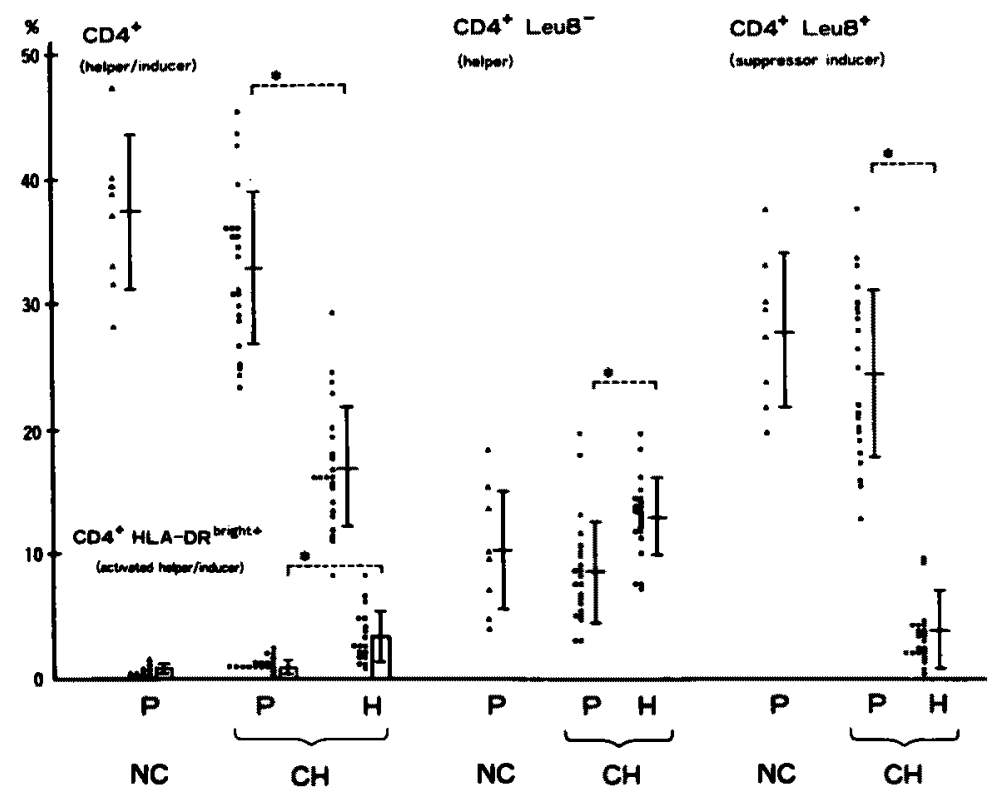

Fig. 6 Percentages of $\mathrm{CD}^{+}, \mathrm{CD}^{+} \mathrm{HLA}-\mathrm{DR}^{\text {brimt+ }}, \mathrm{CD}^{+} \mathrm{Leu}^{-}$, and $\mathrm{CD} 4^{+} \mathrm{Leu}^{+}$ cells. Mean values \pm S.D. are indicated by horizontal bars. Closed triangles $(\boldsymbol{A})$, normal subjects; open circles (O), chronic hepatitis B patients; closed circles (O), chronic hepatitis non-B patients. NC, normal control ; $\mathrm{CH}$, chronic hepatitis ; $P$, peripheral lymphocyte; $H$, intrahepatic lymphocyte. $*, p<0.01$. 


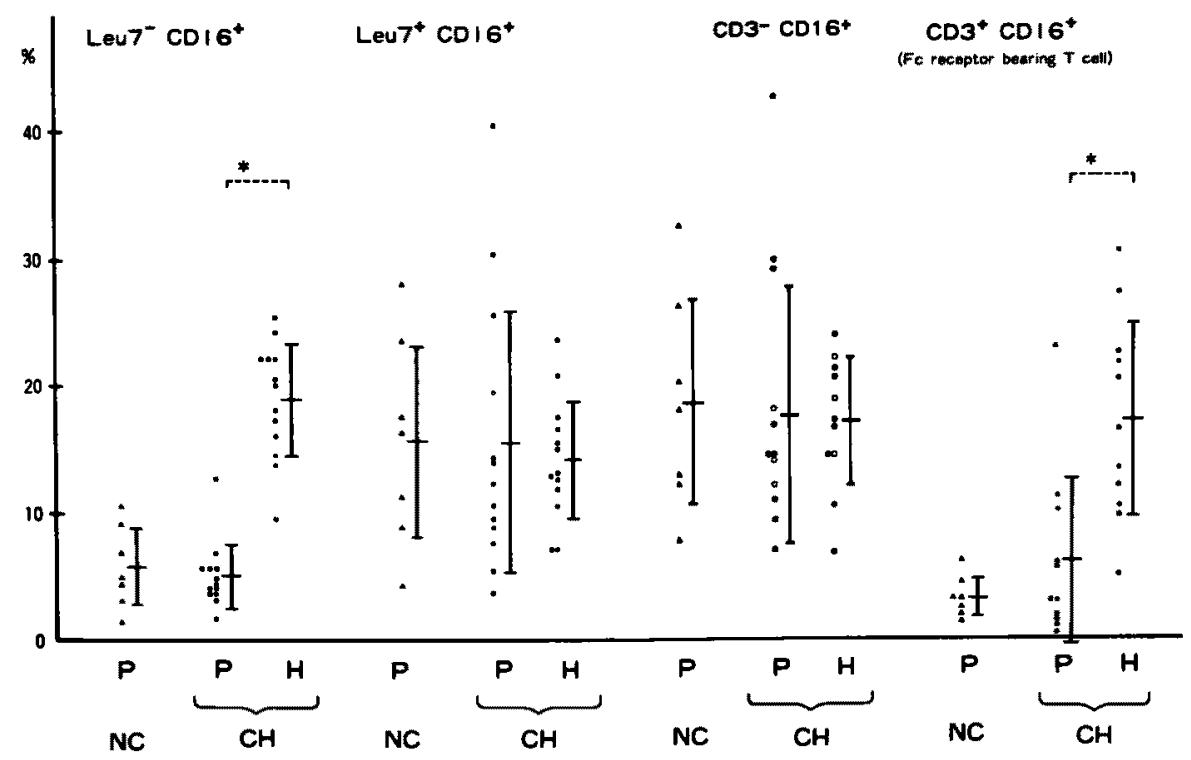

Fig. 7 Percentages of Leu $7^{-} \mathrm{CDI}^{+}, \mathrm{Leu}^{+} \mathrm{CD}^{+} 6^{+}, \mathrm{CD}^{-} \mathrm{CD}^{+} 6^{+}$, and $\mathrm{CD}^{+} \mathrm{CD}^{+} 6^{+}$ cells. Mean values \pm S.D. are indicated by horizontal bars. Closed triangles $(\boldsymbol{A})$, normal subjects; open circles $(O)$, cronic hepatitis B patients; closed circles (O), chronic hepatitis non-B patients. $\mathrm{NC}$, normal control; $\mathrm{CH}$, chronic hepatitis; $\mathrm{P}$, peripheral lymphocyte; $\mathrm{H}$, intrahepatic lymphocyte. $*, \mathrm{p}<0.01$.

であり，肝組織浸潤リンパ球分画の検討が必要である と考完られる。

慢性肝炎患者の肝組倳浸潤 リンパ球については， もっばら免发組織学的検討がなされており CD4/CD8 が減少していることが報告されているが，2 重染色が 困難なため更に詳細な検討は困難であった，今回の flow cytometry を用いた検討では，従来の報告と同様 $に \mathrm{CD} 8$ 陽性細胞の增加，CD4陽性細胞の減少を認めた が,これは cytotoxic $\mathrm{T}$ 細胞, suppressor $\mathrm{T}$ 細胞, helper $\mathrm{T}$ 細胞の増加と suppressor inducer $\mathrm{T}$ 細胞の 著减によるるのであった. cytotoxic T 細胞は肝細胞 障害の effector 細胞の一つとして重要な侱きをして いると考えられるが， suppressor T 細胞の增加の意義 については今後の機能的な解析が必要である. helper T 細胞の増加は，従来の免疫組織学的な検討では明ら かにされていなかった，肝組織内で増加している helper $\mathrm{T}$ 細胞はその約 5 分の 1 が HLA.DR 抗原陽性 の活性型の細胞であり，肝炎の成立に重要な働きを有 していると考兄られる. Ferrari ら ${ }^{(6)}$ は肝組織内浸潤 リンパ球を interleukin 2 (IL2) と HBc 抗原で刺激す ることにより $\mathrm{HBc}$ 杭原特異的に増殖する $\mathrm{T}$ 細胞ク ローンを樹立し，この細胞が $\mathrm{HBc}$ 抗原特巽的に IL2 と interferon (IFN) -gamma を産生し，その細胞表面抗 原は $\mathrm{CD}^{+}, \mathrm{CD}^{+}, \mathrm{CD} 8^{-}, \mathrm{HLA}-\mathrm{DR}^{+}$であったと報告 している. 今回の検討で明かになった活性型の helper T細胞は肝細胞膜に表出されたウイルス蛋白に対し て IL2, IFN-gamma を産生し細胞性免疫の増強に関 与していると推察される。

CD16は IgG に対する Fc receptor（FcR）に関連し た抗原である. 末梢血中のCD16陽性細胞のほとんど は CD3陰性であり NK 細胞障害活性を示すが, CD16 陽性細胞の一部は CD3陽性でHLA に拘束されない 細胞障害活性々抗体依存性細胞障害活性(ADCC)を示 すことが知られている ${ }^{17,18)}$. 今回の検討で明かとなっ た肝組織内での FcR 陽性 $\mathrm{T}$ 細胞の增加は, cytotoxic T細胞を介した細胞障害活性と共に HLA に拘束され ない細胞障害活性やADCC が肝細胞障害に関与して いる可能性を示唆している19.20).

\section{結 論}

慢性肝炎の肝針生検標本からリンハ球を分離し，リ ン八球表面抗原の two-color flow cytometric analysisを行った。本方法により，慢性肝炎の成立には，活 性型 $\mathrm{T}$ 細胞, helper $\mathrm{T}$ 細胞が関与しており，また肝細 胞障害の effector 細胞として cytotoxic $\mathrm{T}$ 細胞と之 
るに Fc receptor-bearing $\mathrm{T}$ 細胞が関与している可能 性が示唆された。本方法は，従来の免疫組織学的方法 に比し，二重染色が容易でより定量的であり，有用な 方法であった。

\section{文献}

1) Dudley FJ, Fox RA, Sherlock S: Cellular immunity and hepatitis-associated, Australia antigen liver disease. Lancet (1) : 723-726, 1972

2) Poralla $T$, Hutteroth TH, Meyer Zum Buschenfelde $\mathrm{K} \cdot \mathrm{H}$ : Cellular cytotoxicity against autologous hepatocytes in acute and chronic non-A, non-B hepatitis. Gut 25: 114-120, 1984

3) Montano L, Aranguibel F, Boffill M, et al : An analysis of the composition of the inflamma. tory infiltrate in autoimmune and hepatitis B virus-induced chronic liver disease. Hepatology $3: 292-296,1983$

4) Colucci G, Colombo M, Ninno ED, et al: In situ characterization by monoclonal antibodies of the mononuclear cell infiltrate in chronic active hepatitis. Gastoenterology 85: 1138 $-1145,1983$

5) Eggink $\mathrm{HF}$, Houthoff $\mathrm{HJ}$, Huitema $\mathrm{S}$, et al: Cellular and humoral immune reactions in chronic active liver disease. II. Lymphocyte subsets and viral antigens in liver biopsies of patients with acute and chronic hepatitis $B$. Clin Exp Immunol 56 : 121-128, 1984

6) Hyodo I, Yamada G, Nagashima H: Cellular immune responses in the acute exacerbation of hepatitis $B e$ antigen-positive type $B$ chronic hepatitis. Gastroenterol Jpn $20: 315-323,1985$

7) Onji M, Kumon I, Kanaoka M, et al : Identification of intrahepatic lymphocyte subpopulations in patients with fulminant hepatitis by the immunoenzymatic technique, using monoclonal antibodies. Hepato-gastroenterol $34: 141-144$, 1987

8) Sasaki H, Kojima T, Matsui S, et al : Interaction of lymphocytes with hepatocytes containing hepatitis $B$ antigen: ultrastructural demonstration of target antigen and $\mathrm{T}$.cell subsets by the peroxidase antibody technique. Virchows Arch A 411: 489-498, 1987

9) Hasegawa K, Yamauchi K, Furukawa $T$, et al : Dual color fluorescencee analysis of peripheral
T cell subsets in hepatitis B virus-induced liver disease. Hepatology $8: 1134-1137,1988$

10) Lanier LL, Le AM, Phillips JH, et al: Subpopulations of human natural killer cells defined by expression of the Leu-7 (HNK-1) and Leu-11 (NK-15) antigens. J Immunol 131: 1789 $-1796,1983$

11) Böyum A: Separation of leucocytes from blood and bone marrow. Scand J Clin Lab Invest 21 (suppl. 97) : 77-89, 1968

12) Goto $M$, Miyamoto $T$, Nishioka $K$ : 2 dimensional flow cytometric analysis of activation antigens expressed on the synovial fluid $T$ cells in rheumatoid arthritis. J Rheumatol 14:230 $-233,1987$

13) Yachie A, Miyawaki $T$, Uwadana $\mathrm{N}$, et al: Sequential expression of $\mathrm{T}$ cell activation ( $\mathrm{Tac}$ ) antigen and Ia determinants on circulating human $\mathrm{T}$ cells after immunization with tetanus toxoid. J Immunol 131 : 731-735, 1983

14) Thomas HC, Brown D, Routhier G, et al: Inducer and suppressor T-cells in hepatitis B virus-induced liver disease. Hepatology 2: 202 $-204,1982$

15) Onji M, Kondo H, Ohta $Y$ : Serial observation of lymphocyte subpopulations and interleukin 2 production of $T$ cells from patients with acute viral hepatitis and chronic active hepatitis. Hepato-gastroenterol 35: 10-13, 1988

16) Ferrari C, Mondelli MU, Penna A, et al: Functional characterization of cloned intrahepatic, hepatitis B virus nucleoprotein-specific helper $\mathrm{T}$ cell lines. J Immunol 139 : 539-544, 1987

17) Lanier LL, Kipps TJ, Phillips JH : Functional properties of a unique subset of cytotoxic $\mathrm{CD} 3+\mathrm{T}$ lymphocytes that express $\mathrm{Fc}$ receptors for IgG (CD16/Leu-11 antigen). J Exp Med 162: 2089-2106, 1985

18) Lanier LL, Phillips JH : Evidence for three types of human cytotoxic lymphocyte. Immunol Today 7: 132-134, 1986

19) Barnaba V, Levrero $M$, Franco $A$, et al: Characterization of effector cells in lymphocytotoxicity to autologous hepatocytes in $\mathrm{HBsAg}$-positive and autoimmune chronic 
active hepatitis (CAH). Liver $6: 45-52,1986$

20) Imawari $M$, Nomura $M$, Kaieda $T$, et al: Establishment of human T-cell clone cytotoxic for both autologous and allogeneic hepatocytes from chronic hepatitis patients with type nonA, non-B virus. Proc Natl Acad Sci USA 86 : 2883-2887, 1989

\title{
Two-color flow cytometry of intraepatic lymphocyte subsets from patients with chronic hepatitis
}

\author{
Tetsuo Takehara*, Norio HaYashi*, Kazuhiro Katayama*, Yutaka SaSaKI*, \\ Akinori Kasahara*, Hideyuki Fusamoto*, Nobuhiro SATo*, \\ Michio Kato**, Manabu MasuzaWA** \\ and Takenobu KAMADA*
}

Peripheral and intrahepatic lymphocyte subsets were analyzed in 22 patients with chronic hepatitis by two-color flow cytometry. Activated $T$ cells in the liver had significantly increased compared with those in the peripheral blood. There were significantly more activated $T$ cells in the livers of the patients whose ALT levels were more than $200 \mathrm{U} / \mathrm{L}$ than in those whose ALT levels were less than $200 \mathrm{U} / \mathrm{L}$ during the one month before liver biopsy. Helper $\mathrm{T}$ cells had increased, but the $\mathrm{CD} 4^{+}$ cells had decreased due to a marked decrease of suppressor inducer $\mathrm{T}$ cells. $\mathrm{CD} 8^{+}$cells had increased due to a increase of both cytotoxic and suppressor $\mathrm{T}$ cells. Fc receptor positive cells, which had increased significantly, were not NK cells but Fc receptor-bearing T cells. In comparison with ordinary immunohistochemical methods, flow cytometric analysis enables more objective quantitation and simpler two-color staining of intrahepatic lymphocyte subsets.

* First Department of Medicine, Osaka University Medical School (Osaka)

** Department of Gastroenterology, National Osaka Hospital (Osaka) 